\title{
EVALUATION OF COVERING MATERIALS IN INDIVIDUAL SHELTERS AND ITS EFFECTS ON PHYSIOLOGICAL RESPONSES AND PERFORMANCE OF DAIRY CALVES
}

\section{PATRÍCIA C. DE F. FONSECA ${ }^{1}$, EDUARDO A. DE ALMEIDA ${ }^{2}$, ROBERTA PASSINI ${ }^{3}$}

\begin{abstract}
In Tropical regions, the animal performance is often affected by climate conditions. This study aimed to evaluate covering materials in individual shelters, normally used to house dairy calves, and its influence on the calves physiology and performance. The design used was completely randomized, with a $2 \times 3$ factorial arrangement to compare the averages of $5 \%$ through the Tukey's test, i.e., both genders- and three types of covering in the shelters ( $\mathrm{Z}$ - zinc; AC asbestos cement; and WPAC - white-painted asbestos cement). Parameters evaluated included daily weight gain (DWG), dry matter intake (DMI), feed conversion (FC), rectal temperature (RT), and respiratory frequency $(\mathrm{RF})$. Results showed significant differences $(\mathrm{P}<0.05)$ among males $(1.04 \mathrm{~kg} /$ day $)$ and females $(0.74 \mathrm{~kg} /$ day $)$ for $\mathrm{DWG}$ and interaction between gender and treatment $(\mathrm{P}<$ $0.05)$ for zinc covering $(0.562 \mathrm{~kg} /$ day for females and $1.120 \mathrm{~kg} /$ day for males $)$. Significant differences were also observed in FI of animals housed under shelters with the covering of zinc (48.35kgDM/day for females and $96.91 \mathrm{kgDM} /$ day for males). There were no significant differences $(\mathrm{P}>0.05)$ in the FC and the RT, and there were significant differences $(\mathrm{P}<0.05)$ for RF in the $\mathrm{Z}$ treatments $\left(56.9\right.$ mov. $\left.\mathrm{min}^{-1}\right)$, WPAC $\left(62.2 \mathrm{mov} \cdot \mathrm{min}^{-1}\right)$ and FC $\left(70.25 \mathrm{mov}^{\mathrm{min}} \mathrm{m}^{-1}\right)$. It was concluded that different covering materials did not affect performance and dry matter intake of dairy calves. However, the animals' physiology of thermoregulation was altered by the different covering materials used in individual shelters.
\end{abstract}

KEYWORDS: thermoregulation, weight gain, feed conversion.

\section{AVALIAÇÃO DE MATERIAIS DE COBERTURA EM ABRIGOS INDIVIDUAIS SOBRE RESPOSTAS FISIOLÓGICAS E DESEMPENHO DE BEZERROS LEITEIROS}

RESUMO: Nos trópicos, o desempenho animal é prejudicado pela ação do clima. Objetivou-se neste trabalho avaliar materiais de cobertura em abrigos individuais sobre a fisiologia e o desempenho de bezerros leiteiros. Utilizou-se o delineamento inteiramente casualizado, fatorial $2 \mathrm{X}$ 3, para a comparação das médias ao nível de 5\%, pelo teste de Tukey, ou seja, dois sexos e três tipos de coberturas ( $Z$ - zinco; $C A$ - cimento-amianto e $C A B$ - cimento-amianto pintado de branco). Foram medidos o ganho de peso diário (GPD), o consumo alimentar (CMS), a conversão alimentar (CA), a temperatura retal (TR) e a frequência respiratória (FR). Os resultados mostraram que houve diferença significativa $(\mathrm{P}<0,05)$ entre machos $(1,04 \mathrm{~kg} / \mathrm{dia})$ e fêmeas $(0,74 \mathrm{~kg} / \mathrm{dia})$ para GPD, interação sexo e tratamento $(P<0,05)$ para a de cobertura de zinco $(0,562 \mathrm{~kg} / \mathrm{dia}$ para fêmeas e $1,120 \mathrm{~kg} /$ dia para machos), e o CMS apresentou diferença significativa para cobertura de zinco (48,35 kgMS/dia para fêmeas e 96,91 kgMS/dia para machos). Não houve diferença significativa ( $\mathrm{P}$ $>0,05)$ para CA e TR e observou-se diferença significativa $(\mathrm{P}<0,05)$ para FR nos tratamentos $\mathrm{Z}$ $\left(56,9\right.$ mov.min $\left.{ }^{-1}\right)$, CAB $\left(62,2\right.$ mov. $\left.\mathrm{min}^{-1}\right)$ e CA $\left(70,25 \mathrm{mov} \cdot \mathrm{min}^{-1}\right)$. Conclui-se que os diferentes tipos de coberturas não influenciaram no desempenho e no consumo alimentar, mas interferiram na fisiologia de termorregulação dos animais.

PALAVRAS-CHAVE: termorregulação, ganho de peso, conversão alimentar.

\footnotetext{
${ }^{1}$ Mestre em Engenharia Agrícola, Docente Universidade Estadual de Goiás, UEG, Santa Helena de Goiás - GO.

${ }^{2}$ Mestrando em Zootecnia, Faculdade de Ciências Agrárias e Veterinárias, UNESP, Jaboticabal - SP.

${ }^{3}$ Doutora em Zootecnia, Docente Universidade Estadual de Goiás, UEG, Anápolis - GO.

Recebido pelo Conselho Editorial em: 20-12-2010

Aprovado pelo Conselho Editorial em: 3-8-2012
} 


\section{INTRODUCTION}

In tropical countries like Brazil, one of the main limiting factors for animal welfare and to achieve a good yield are environmental factors, which include high temperatures and high humidity within the facilities, causing stress to the animal and consequent decreased production (SOUSA, 2005).

According to CARMO (2008), is of utmost importance that the production facilities promote animal comfort, because in situations of stress the animal tends to increase its rectal temperature and respiratory rate, beyond decreasing significantly its productive performance. It is noteworthy that when the animal is outside its thermal comfort zone there is an impairment of heat production with high mortality rates, problems in animal health, reduction in weight gain and in the final product quality (RODRIGUES, 2010).

According to TINOCO (2001), when the room temperature is outside the thermal comfort zone, the development of animal and feed conversion efficiency are compromised due to fall in food intake induced by heat. This helps the animal homeothermy, but brings in economic loss to the producer.

MATARAZZO (2006) emphasized the importance of the materials used in the manufacture of coverings have properties that allow better reflection of the sunbeams in order to reduce the thermal indexes within the facilities.

According to PERISSINOTTO (2006), milk production in the tropics is lower when compared to northern hemisphere countries, and the main problem is the adaptation of dairy breeds of European origin, which, due to its high productivity, often suffer problems of physiological and behavioral changes induced by thermal stress, causing a reduction in milk production.

In situations of thermal stress, cattle increases water consumption, reduce food intake and increase significantly the rectal temperature, surface temperature and respiratory rate (MARQUES et. al., 2006; FERREIRA, 2005).

SILANIKOVE (2000) suggests a classification of the condition of thermal stress in animals through the respiratory rate, i.e., 40 - 60mov. $\mathrm{min}^{-1}, 60-80 \mathrm{mov}^{\mathrm{min}} \mathrm{m}^{-1}, 80-120 \mathrm{mov} \cdot \mathrm{min}^{-1}$ and above 120 mov. $^{-1}{ }^{-1}$ corresponding that the animals present low, medium, high and severe stress conditions, respectively.

According to BAÊTA \& SOUZA (2010), coverings are responsible for promoting a more suitable environment for animal production, whereas the use of shelters with various coating materials such as shade cloth, fibrocement, etc., promote the reduction of up to $30 \%$ of radiant thermal load when compared to the received by animals outdoors improving the thermal comfort condition.

This study evaluated the influence of three types of covering, i.e., Z - Zinc, AC - asbestos cement; and WPAC - white-painted asbestos cement, in individual shelter for calves, regarding to their thermoregulation physiological responses, as rectal temperature and respiratory rate, and regarding to animal performance, such as weight gain, dry matter intake and feed conversion.

\section{MATERIAL AND METHODS}

This experiment was conducted in the Fazenda Sol Dourado, a farm located on Highway GO 437, $\mathrm{km} \mathrm{14}$, in the municipality of Gameleira of Goiás - in the state of Goiás (GO), Brazil. The city is in the $16^{\circ} 25^{\prime} 29.68^{\prime} \mathrm{S}$ latitude, $48^{\circ} 48^{\prime} 11.55^{\prime} \mathrm{W}$ longitude and $1,032 \mathrm{~m}$ altitude. According to Köppen climate classification, the region climate is Aw (mesoclimatic characteristics: semi-humid tropical rainfall pattern with well-defined dry season and hot thermal regime).

The experiment was conducted between March and May, 2009, with ten days reserved for the adaptation of animals to the management of the hutches and seventy days for the measurements. The experimental design was the completely randomized design (CRD) with factorial arrangement 
of treatments $2 \times 3$, i.e., two genders (male and female) and three coverings managements ( $\mathrm{Z}$ - Zinc, AC - Asbestos Cement and WPAC - White-Painted Asbestos Cement on top of the tiles).

It was used eighteen purebred Holstein calves (PO), from birth to 5 days of age, nine males and nine females that were weighed at the beginning of the experiment and randomly assigned to the treatments.

It was given two liters of milk twice a day during the experiment, as well as water ad libitum, with an interval of one hour between them. The complete pelleted Ration was provided after the first week of life, once a day and at ease.

The correction of the dry matter in relation to food intake was calculated by the dry matter intake (kgDM/animal/day), where the remains of each animal's ration were evaluated weekly and stored in a freezer for analysis of the content of dry matter. The drying of the ration for analysis of dry matter content was performed at the Laboratory of Drying and Storage of Vegetable Products of the State University of Goiás, in the city of Anápolis - GO. The samples were weighed and then kept in an incubator for a period of 48 hours at a temperature of $65^{\circ} \mathrm{C}$, and then weighed again. By subtracting the final weight of the initial weight it was determined dry matter content.

The food intake was measured daily by weighing the ration supplied and its remains in a balance with accuracy of $5 \mathrm{~g}$. The animal performance was evaluated by the weight gain every 10 days, always in the morning using a measuring tape, as shown in Figure 1, and subsequently the daily weight gain $(\mathrm{kg} / \mathrm{day})$ is determined. The feed conversion was calculated as the ratio between the amount of food consumed in $\mathrm{kgDM} /$ animal/day by the daily weight gain $(\mathrm{kg} / \mathrm{day})$ for each animal.

The physiological parameters analyzed were the rectal temperature and respiratory rate, which were collected in all animals, every two days, always at 2 p.m., considered as the time of the greatest thermal discomfort (FIORELLI, 2009).

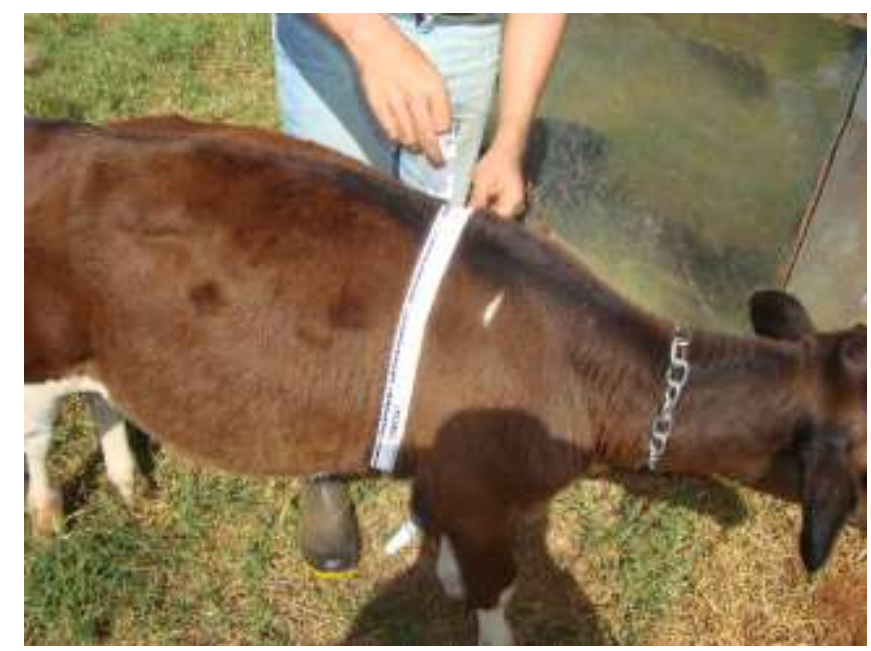

FIGURE 1.Weighing of the animals using a measuring tape.

The rectal temperature was measured with a digital thermometer, remaining in the rectum of the animal for about two minutes, as shown in Figure 2. The measurement of respiratory rate was carried out by counting the respiratory movements in the flank region for 30 seconds to subsequently calculate the respiratory movements per minute. These data were collected every two days, totaling 34 collections. 


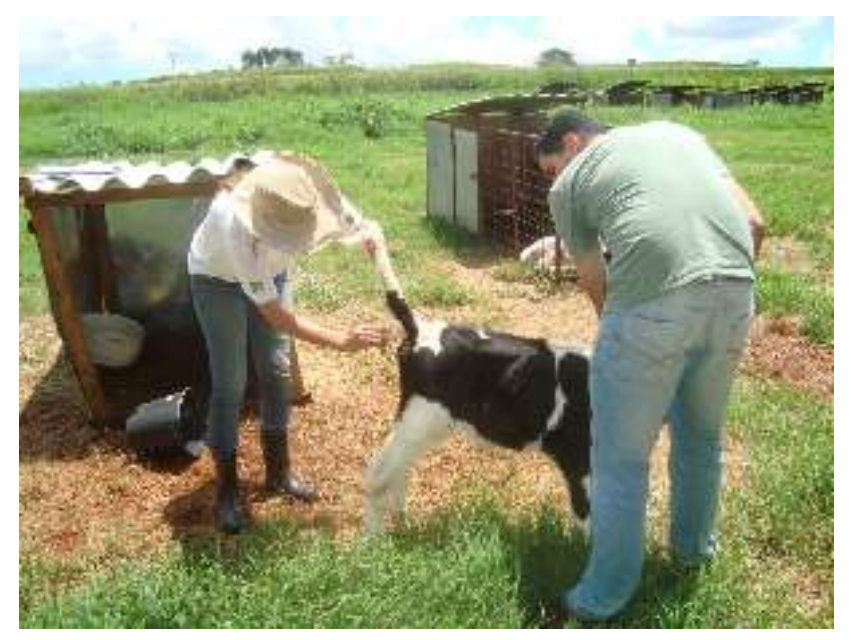

FIGURE 2. Taking rectal temperature.

Statistical analysis was performed using the SISVAR program (free). It was checked the homogeneity of variances and normality of residuals as premises for application of parametric statistics. The Hartley test was performed to verify the homogeneity of variance, using the square root transformation, when necessary. The Tukey's test was used to compare the averages, considering $5 \%$ of significance.

\section{RESULTS AND DISCUSSION}

It was observed an interaction between gender and treatment in the data analysis $(\mathrm{P}<0.05)$ for weight gain and dry matter intake.

Table 1 shows the average values for daily weight gain (DWG), dry matter intake (DMI) and feed conversion (FC) in the different treatments and their interactions.

TABLE 1. Daily weight gain (DWG), dry matter intake (DMI) and feed conversion (FC) averages for the different treatments and statistical probabilities.

\begin{tabular}{|c|c|c|c|c|}
\hline \multirow{2}{*}{ Treatment } & \multirow{2}{*}{ Gender } & DWG (kg/day) & DMI (kgDM/day) & $\mathrm{FC}$ \\
\hline & & \multicolumn{3}{|c|}{ Interaction } \\
\hline \multirow{2}{*}{$\mathrm{Z}$} & Females & $0.562 \mathrm{~b}$ & $48.35 \mathrm{~b}$ & 1.15 \\
\hline & Males & $1.120 \mathrm{a}$ & $96.91 \mathrm{a}$ & 1.27 \\
\hline \multirow{2}{*}{$\mathrm{AC}$} & Females & $0.667 \mathrm{~b}$ & $66.37 \mathrm{a}$ & 1.45 \\
\hline & Males & $1.000 \mathrm{a}$ & $49.23 \mathrm{a}$ & 0.92 \\
\hline \multirow{2}{*}{ WPAC } & Females & $1.000 \mathrm{a}$ & $64.92 \mathrm{a}$ & 1.42 \\
\hline & Males & $1.000 \mathrm{a}$ & $58.94 \mathrm{a}$ & 1.12 \\
\hline \multicolumn{5}{|l|}{ Main Effects } \\
\hline Females & & $0.743 \mathrm{~b}$ & 59.88 & 1.34 \\
\hline Males & & $1.039 \mathrm{a}$ & 68.36 & 1.10 \\
\hline $\mathrm{Z}$ & & 0.833 & 72.63 & 1.21 \\
\hline $\mathrm{AC}$ & & 0.841 & 57.79 & 1.19 \\
\hline WPAC & & 1.000 & 61.93 & 1.27 \\
\hline Average & & 0.891 & 64.12 & 1.22 \\
\hline C.V. & & 16.66 & 22.46 & 25.46 \\
\hline \multicolumn{5}{|l|}{ Probabilities } \\
\hline Treatment & & 0.1316 & 0.2248 & 0.8814 \\
\hline Gender & & 0.0011 & 0.2357 & 0.1310 \\
\hline Gender*Treatment & & 0.0218 & 0.0042 & 0.2242 \\
\hline
\end{tabular}

$\mathrm{Z}$ - galvanized zinc; AC - asbestos cement; WPAC - White-painted asbestos cement. Averages, in the columns, followed by the same letter do not differ by the Tukey's test at $5 \%$ of probability. 
There was a significant effect of gender $(\mathrm{P}<0.05)$, that was observed a higher DWG in males, reaching an average of $1.039 \mathrm{~kg}$; compared to females that was of $0.743 \mathrm{~kg}$. However, in the WPAC treatment, females did not differ from males regarding to weight gain, showing that the covering with white paint management was able to match the performance of the animals, regardless of the gender.

There was no significant difference between the coverings studied and the gender for dry matter intake $(\mathrm{P}>0.05)$; however, there was an interaction between gender and treatment $(\mathrm{P}<0.05)$ in $\mathrm{Z}$ covering, where females had lower DMI compared to males. The dry matter intake was higher for males, with $96.91 \mathrm{KgDM} /$ day, while females showed a consumption of $48.35 \mathrm{KgDM} / \mathrm{day}$.

There was no impairment of performance in relation to the evaluated coverings managements; however, WPAC promoted better gains in females compared to AC and Z, considering the same food intake.

Table 2 shows the average physiological responses for the different treatments with the respective statistical probabilities.

TABLE 2. Respiratory rate (RR) and rectal temperature (RT) averages for the different treatments, statistical probabilities and coefficient of variation.

\begin{tabular}{llll}
\hline Treatment & Gender & RR $\left(\mathrm{mov}^{-m^{-1}}\right)$ & $\mathrm{RT}\left({ }^{\circ} \mathrm{C}\right)$ \\
\hline Interactions & & & \\
\hline $\mathrm{Z}$ & Females & $53.53 \mathrm{a}$ & $39.40 \mathrm{a}$ \\
& Males & $60.40 \mathrm{a}$ & $39.36 \mathrm{a}$ \\
\hline $\mathrm{AC}$ & Females & $66.77 \mathrm{a}$ & $40.03 \mathrm{a}$ \\
& Males & $73.73 \mathrm{a}$ & $39.57 \mathrm{a}$ \\
\hline WPAC & Females & $60.80 \mathrm{a}$ & $39.53 \mathrm{a}$ \\
& Males & $63.63 \mathrm{a}$ & $39.43 \mathrm{a}$ \\
\hline Main Effects & & 39.65 \\
\hline Females & & 39.45 \\
Males & & $60.37 \mathrm{~b}$ & 39.38 \\
\hline Z & $65.92 \mathrm{a}$ & 39.80 \\
AC & $56.97 \mathrm{~b}$ & 39.48 \\
WPAC & $70.25 \mathrm{a}$ & 39.55 \\
\hline Average & $62.22 \mathrm{~b}$ & 0.71 \\
\hline C.V. & 63.14 & 0.0606 \\
\hline Probability & 7.63 & 0.1581 \\
\hline Treat. & & 0.3872 \\
Gender & & 0.0016 & \\
Treat $*$ Gender & 0.0308 & \\
\hline
\end{tabular}

Averages, in the columns, followed by the same letter do not differ by the Tukey's test at 5\% of probability. Z - Galvanized Zinc; AC - Asbestos Cement; WPAC - White-Painted Asbestos Cement.

There was no interaction between gender and treatment for physiological thermoregulation: respiratory rate and rectal temperature; however, it was observed the main effects of gender and treatment $(\mathrm{P}<0.05)$ for the respiratory rate.

There was increased respiratory rate in males with $65.92 \mathrm{mov} \cdot \mathrm{min}^{-1}$, while for females it was verified $60.37 \mathrm{mov} \cdot \mathrm{min}^{-1}$, representing a decrease of $8 \%$. Regarding the management of the AC

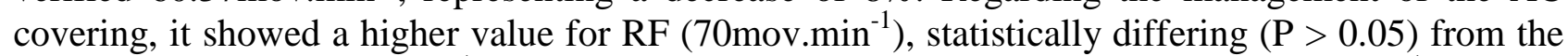
zinc covering (56.9mov. $\left.\mathrm{min}^{-1}\right)$ and from the white-painted asbestos cement $\left(62.2 \mathrm{mov} \cdot \mathrm{min}^{-1}\right)$.

Considering these results, it can be stated that the animals in the treatment of AC and WPAC remained in a medium stress during the period they were housed, and the animals installed in the $\mathrm{Z}$ were in a low-stress stage, as suggested by SILANIKOVE (2000). This may be due to the 
difference in the balance of long-wave radiation compared to other materials and the high capacity of the zinc has in reflection and heat dissipation.

MARTELLO (2002) mentions that the critical respiratory rate for cows is 60 mov. $\mathrm{min}^{-1}$, indicating that only the zinc covering provided a desirable environment regarding physiological thermoregulation; since the RF presented a result lower than the critical value.

There was no difference $(\mathrm{P}>0.05)$ for rectal temperature between treatments, and there was also no interaction between gender and treatment $(\mathrm{P}>0.05)$. When an animal is in a state of thermal stress, the first thermoregulation mechanism used by the animal to maintain its body temperature is the respiratory rate, to promote the heat loss via evaporation, then it is concluded that the increase in respiratory frequency was sufficient to dissipate the absorbed heat while maintaining the homeothermy of the animals. According to a study by KAWABATA et. al (2005) about the physiological responses of Holstein calves, with coverings of asbestos cement, cellulose-cement, double roof and painted roof; these showed no significant difference $\left(54.2 \mathrm{mov} \mathrm{min}^{-1}, 54.7 \mathrm{mov} \cdot \mathrm{min}^{-}\right.$ 1, 56.2mov. $\mathrm{min}^{-1}$ and 53.9mov. $\mathrm{min}^{-1}$, respectively).

Regarding the rectal temperature, a study by CUNHA et. al. (2007) during the rainy season, i.e., from 12/20/2001 to 04/05/2002, in the Barão Juparanã district, in the municipality of Valença, in the state of Rio de Janeiro (RJ), found average values of rectal temperature of $39.3^{\circ} \mathrm{C}, 39.3^{\circ} \mathrm{C}$ and $39.8^{\circ} \mathrm{C}$ in calves in the afternoon, housed in mobile shelters with zinc covering and laterals of bamboo, under shade cloths and in open air, respectively. During the dry season, the average values for rectal temperature were $39.2^{\circ} \mathrm{C}, 39.2^{\circ} \mathrm{C}$ and $39.5^{\circ} \mathrm{C}$ for zinc covering, sombrite and in open air, respectively.

The values of rectal temperature in the studied treatments showed below those found by DAS et al. (1999), who found values of rectal temperature of buffalo calves, at 2 p.m., at the same time of this study, of $39.97^{\circ} \mathrm{C}$, also superior from those found by CUNHA et al. (2007). Although it was seen a higher RF for AC and for males compared to females, the increase in RF was sufficient to promote heat transfer and maintain homeothermy, since the rectal temperatures did not increase.

\section{CONCLUSIONS}

The male calves presented higher daily weight gain compared to females; however, the management of white paint on the covering favored similar weight gains between males and females.

The management of white paint on the covering did not influence dry matter intake and feed conversion, however it reduced respiratory rate.

The management of the coverings did not affect the rectal temperature of the animals evaluated, because the increase in respiratory rate was sufficient to dissipate the heat absorbed by the animals

\section{REFERENCES}

BAÊTA, F. C.; SOUZA, C. F. Ambiência em edificações rurais - Conforto animal. 2ed. Viçosa: Editora UFV, 2010. 269 p.

CARMO, T. J. D. Planejamento de instalações para bovinos leiteiros e o seu impacto na saúde animal. 2008. 90f. Dissertação (Mestrado Integrado em Medicina Veterinária) - Faculdade de Medicina Veterinária, Universidade Técnica de Lisboa, Lisboa, 2008.

CUNHA, D. N. F. V.; CAMPOS, O. F.;PEREIRA, J. C.; PIRES, M. F. Á.; LIZIEIRE, R. S.; MARTUSCELLO, J. A. Desempenho, variáveis fisiológicas e comportamento de bezerros mantidos em diferentes instalações: época chuvosa. Revista Brasileira de Zootecnia, Viçosa, v.36 n.4 2007.

DAS,S.K.; UPADHYAY, R.C.; MANDAN, M. L. Heat stress in Murrah calves. Production Science, Livestock, v.61, p.71-78, 1999. 
FERREIRA, R. A. Maior produção com melhor ambiente para aves, suínos e bovinos. Viçosa: Aprenda Fácil, 2005. 371p.

FIORELLI, J.; MORCELI, J. A. B.; VAZ, R. I.; DIAS, A. A. Avaliação da Eficiência Térmica de Telha Reciclada à Base de Embalagens Longa Vida. Revista Brasileira de Engenharia Agrícola e Ambiental, Campina Grande, PB, v.13, n.2, p.204-209, 2009.

KAWABATA, C. Y; CASTRO R.C; H. SAVASTANO JÚNIOR. Índices de conforto térmico e respostas fisiológicas de bezerros da raça holandesa em bezerreiros individuais com diferentes coberturas. Engenharia Agrícola, Jaboticabal, v.25, n.3, p.663-671, set./dez. 2005.

MARQUES, J. A.; NETO, S. F. C.; GROFF, A. M.; SIMONELLI, S. M.; CORASA, J. ROMERO, L.; ZAWADSKI, F.; ARAÚJO, P. F. Comportamento de bovinos mestiços em confinamento com e sem acesso a sombra durante o período de verão. Campo Digital, Campo Mourão, v.1, n.1, p.54-59, jul./dez. 2006.

MARTELLO, L.S. Diferentes recursos de climatização e sua influência na produção de leite, na termorregulação dos animais e no investimento das instalações. 2002. 67f. Dissertação (Mestrado em Zootecnia) - Faculdade de Zootecnia e Engenharia de Alimentos, Universidade de São Paulo, Pirassununga, 2002.

MATARAZZO, S. V.; SILVA, I. J. O.; PERISSINOTO, M.; FERNANDES, S. A. A. Intermitência do sistema de resfriamento adiabático evaporativo por aspersão em instalação para vacas em lactação. Engenharia Agrícola, Jaboticabal, v.26, n.3, p.654-662, set./dez. 2006.

PERISSINOTTO, M.; MOURA, D. J.; MATARAZZO, S. V.; SILVA, I. J. O.; LIMA, K. A. O. Efeito da Utilização de Sistemas de Climatização nos Parâmetros Fisiológicos do Gado Leiteiro. Engenharia Agrícola, Jaboticabal, v.26, n.3, p.663-671, set./dez. 2006.

RODRIGUES, A. L.; SOUZA, B. B.; FILHO, J. M. P. Influência do Sombreamento e dos sistemas de Resfriamento no Conforto Térmico de Vacas Leiteiras. ACSA - Agropecuária Científica no Semi- Árido, v. 6, n.2, p.14-22, abr./jun. 2010.

SILANIKOVE, E. Effects of heat stress on the welfare of extensively managed domestic ruminants. Production Science, Livestock, v.67, p1-18, 2000.

SOUSA, P. Avicultura e clima quente: como administrar o bem estar às aves. Embrapa Suínos e Aves, Área de transferência de Tecnologia, 2005.

TINÔCO, I.F.F.; Avicultura industrial: novos conceitos de materiais, concepções e técnicas construtivas disponíveis para galpões avícolas brasileiros. Revista Brasileira de Ciência Avícola, Campinas, v.3, n.1, p.1-26, 2001. 